\title{
An Approach to the Cephalotaxine Ring Skeleton Using an Ammonium Ylide/Stevens [1,2]-Rearrangement
}

\author{
L. Scott Beall and Albert Padwa* \\ Department of Chemistry, Emory University, Atlanta, Georgia 30322
}

Received 3 March 1998; accepted 6 April 1998

Abstract: Ammonium ylides derived from the $\mathrm{Cu}$ (II)-catalyzed decomposition of $\alpha$ diazo carbonyls tethered to tertiary amines underwent a benzylic Stevens $[1,2]-$ rearrangement to give tetrahydroisoquinolines or benzazepines containing fused five-membered rings, a feature found in the cephalotaxus and lycorane alkaloids.

(1) 1998 Elsevier Science Ltd. All rights reserved.

The tandem ammonium ylide generation/rearrangement sequence represents an effective method for the preparation of nitrogen-containing heterocycles. ${ }^{1}$ A typical example involves the ring expansion reaction of a spirocyclic ammonium ylide such as 3 which has been nicely exploited for the synthesis of a number of alkaloids. Thus, the key step in West and Naidu's enantioselective synthesis of (-)-epilupinine ${ }^{2}$ involved the ammonium ylide-Stevens [1,2]-rearrangement of the (L)-proline derivative 1 which furnished the advanced intermediate 4 in $84 \%$ yield and with $76 \%$ ee. Starting from a related ( $L$ )-proline derivative 2 ( $R=v$ inyl), Clark and Hodgson synthesized the $C E$ ring system 5 in their approach to the Mazamine A ring skeleton via an ammonium ylide-[2,3]-sigmatropic rearrangement (Scheme 1)..$^{3,4}$

\section{Scheme 1}
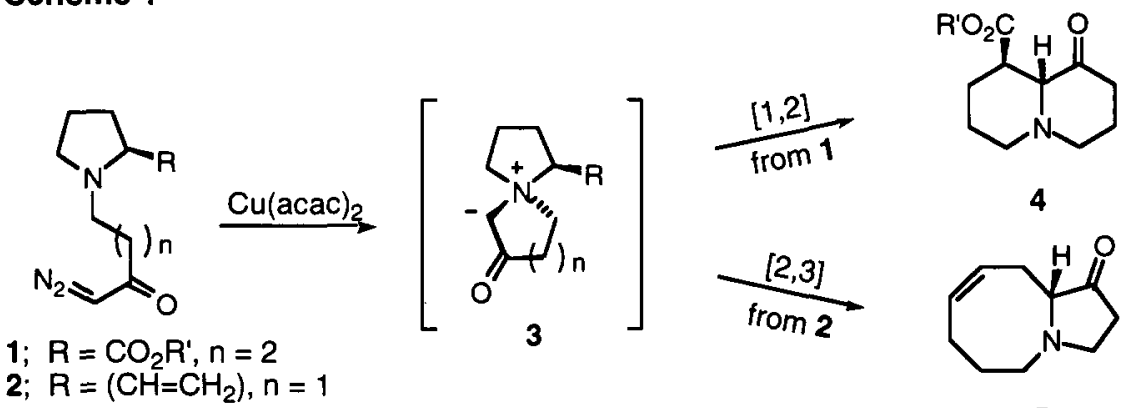

5

As part of our ongoing program directed toward the synthesis of complex alkaloids via the tandem metallocarbenoid generation/ylide rearrangement cascade, ${ }^{5,6}$ we became interested in using this strategy for the assemblage of the 5,7-fused ring framework found in cephalotaxine (6). ${ }^{7}$ Starting from diazo precursors readily prepared from secondary amines, our interest was directed toward developing facile routes for the synthesis of related benzazepine and tetrahydroisoquinoline ring systems. This motif is prevalent in many natural products such as the cephalotaxus and lycorane family of alkaloids. ${ }^{8}$ We now wish to report results from a study of the tandem intramolecular formation and Stevens $[1,2]$-rearrangement of ammonium ylides which demonstrates the scope of this process for the synthesis of the 5,7-fused benzazepine skeleton found in cephalotaxine. 
Cephalotaxine 6 is the major alkaloidal constituent isolated from Cephalotaxus harringtonia, ${ }^{9}$ an evergreen tree native to southern China. Cephalotaxine is of considerable interest due to the biological activity of its ester derivatives, harringtonine $(\mathrm{HT})$ and homoharringtonine $(\mathrm{HHT}){ }^{10}$ The latter compound has demonstrated efficacy in the treatment of myeloid leukemia, myelodysplastic syndrome, carcinomas, ${ }^{11}$ and chloroquinine-resistant malaria. ${ }^{12}$ Along with harringtonine, HHT is widely used in China and was selected for Phase I and II trials in the United States. ${ }^{12}$<smiles>COC1CC23CCCN2CCc2cc4c(cc2C3[C@@H]1O)OCO4</smiles>

(-)-Cephalotaxine, $\mathrm{R}=\mathrm{H}(6)$<smiles>[3H]P=CC(=O)C(O)(CCC(C)(C)O)CC(=O)OC</smiles><smiles>COC(=O)CC(O)(CCCC(C)(C)O)C(=O)C=C=P</smiles>

In addition to the promising biological activity, the five-membered spiro-fused ring annular to the benzazepine system makes cephalotaxine an intriguing synthetic target. The cephalotaxus alkaloids have served as the focal point for a number of synthetic efforts aimed at developing and demonstrating the preparative power of various methods to construct the core skeleton. ${ }^{13}$ Eight total syntheses of cephalotaxine have been reported. ${ }^{14}$ To date, only Mori has reported a non-racemic synthesis which is derived from alkene intermediate $7 .^{15}$ Our overall plan, outlined below, relies on a transition metal catalyzed ammonium ylide-Stevens $[1,2]$-rearrangement ${ }^{1}$ followed by a subsequent alkylidine-catalyzed ring-closure metathesis ${ }^{16}$ as the key synthetic steps (Scheme 2). There exists a significant body

\section{Scheme 2}

6<smiles>C=CCOc1cc2c(C3C=CC4CCN5CCC(C4)C35)cc1OCO2</smiles><smiles></smiles><smiles></smiles><smiles>[CH]=C</smiles>

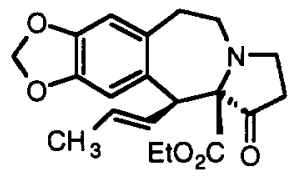
9<smiles>C=C</smiles><smiles>C/C=C/[C@H]1NCCc2cc3c(cc21)OCO3</smiles><smiles>C=CC(=O)C(=[W])C(=O)OCC</smiles>

12

of work on the formation of onium ylides by reaction of metal carbenoids, generated catalytically from diazo carbonyl compounds, with heteroatom containing substrates. ${ }^{1,17}$ The ability to further utilize the ylide by a subsequent rearrangement reaction enhances the utility of this method toward complex syntheses. The notion of coupling a cyclic amine with the unsaturated diazo keto ester 12 was particularly attractive as a subsequent transition metal catalyzed-cyclization reaction would generate 
the key spirocyclic ammonium ylide 21 (Scheme 3).

To explore the feasibility of the ammonium ylide-Stevens [1,2]-shift in our proposed cephalotaxine sequence, we first prepared diazo keto ester 12 from a diazo transfer reaction of the corresponding $\alpha, \beta$ unsaturated keto ester. ${ }^{18}$ Addition of 12 to a solution of the readily available secondary amines 13-16 in $\mathrm{CH}_{2} \mathrm{Cl}_{2}$ at $25^{\circ} \mathrm{C}$ afforded the desired amino keto esters $17-20$ in $78 \%-96 \%$ yield by conjugate addition. Early attempts at cyclization were made using rhodium based catalyst systems, but the reactions were observed to be sluggish, resulting in complex mixtures of products due to the extended reaction times. Copper catalysis was found to be a superior alternative for effecting the desired rearrangement. ${ }^{19}$ The $\mathrm{Cu}(\mathrm{acac})_{2}$-catalyzed decomposition of the diazo compounds in toluene at reflux for $1 \mathrm{~h}$ furnished the rearranged 5,7-fused systems $22-25$ in $68-77 \%$ yield. ${ }^{20}$ The formation of these ring expanded products can be attributed to the initial formation of ammonium ylide 21 followed by a preferential Stevens [1,2]-

Scheme 3

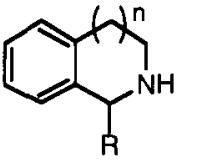

13; $n=0, R=H$

14; $n=1, R=H$

15; $n=1, \mathrm{R}=\mathrm{CH}_{3}$

16; $n=1, \mathrm{R}=\left(\mathrm{CH}=\mathrm{CHCH}_{3}\right)$

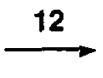<smiles>CCOC(=O)C(=N)C(=O)CCN1CCCC1C(=O)OCC</smiles>

$17(78 \%)$

$18(96 \%)$

$19(78 \%)$

$20(82 \%)$<smiles></smiles><smiles>[R]C1c2ccccc2CCN2CCC(=O)C12C(C)C(=O)OC</smiles>

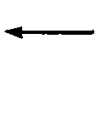

$22(68 \%)$

$23(73 \%)$

$24(77 \%)$

$25(77 \%)$

shift of the benzylic carbon atom. ${ }^{21}$ Interestingly, in the case of 18 it was possible to isolate ylide $21(\mathrm{R}=\mathrm{H}$; $n=1$ ) as a white crystalline solid. Further heating of the ylide in the absence of the Cu-catalyst cleanly afforded 23 in high yield. The reaction sequence works well for both five (13) and six-membered (1416) ring amine precursors leading to tetrahydroisoquinolines (22) or benzazepines (23-25), respectively, which contain the required fused five-membered ring present in many natural product systems.

Further studies are currently underway to determine the scope of the reaction with regard to ring size, ring substitution, catalytic effects and its further application to the synthesis of cephalotaxine and related target molecules.

Acknowledgment: We gratefully acknowledge support of this work by the National Institutes of Health (CA-26751). L. S. B. is pleased to acknowledge the NIH for a postdoctoral fellowship (CA 74500-01A1). 


\section{References}

1. Padwa, A.; Hornbuckle, S. F. Chem. Rev. 1991, 91, 263. Ye, T.; McKervey, A. M. Chem. Rev. 1994, 94, 1901.

2. West, F. G.; Naidu, B. N. J. Am. Chem. Soc. 1993, 115, 1177. West, F. G.; Glaeske, K. W.; Naidu, B. N. Synthesis 1993, 977. Naidu, B. N.; West, F. G. Tetrahedron 1997, 53, 16565.

3. Clark, J. S.; Hodgson, P. B. J. Chem. Soc., Chem. Commun. 1994, 2701. Clark, J. S.; Hodgson, P. B. Tetrahedron Lett. 1995, 36, 2519.

4. Wright, D. L.; Weekly, R. M.; Groff, R.; McMills, M. C. Tetrahedron Lett. 1996, 37, 2165.

5. Curtis, E. A.; Worsencroft, K. J.; Padwa, A. Tetrahedron Lett. 1997, 38, 3319.

6. Padwa, A.; Brodney, M. A.; Marino, J. P., Jr.; Sheehan, S. M. J. Org. Chem. 1997, 62, 78. Padwa, A.; Price, A. T. J. Org. Chem. 1998, 63, 556.

7. Huang, L.; Xue, Z. In The Alkaloids; Brossi, A., Ed.; Academic Press: New York, 1984; Vol. 23, Chapter 3.

8. Smith, C. R., Jr.; Mikolajczak, K.; Powell, R. G. In Medicinal Chemistry. Anticancer Agents Based on Natural Product Models; Cassady, J. M., Duros, J. D., Eds.; Academic Press: New York, 1980; Vol. 16, Chapter 11.

9. Wickremesinhe, R. M.; Arteca, R. N. J. Liq. Chrom. \& Rel. Technol. 1996, 19, 889.

10. Hudlicky, T.; Kwart, L. D.; Reed, J. W. In Alkaloids. Chemical and Biological Perspectives; Pelletier, S. W., Ed.; Springer Verlag: New York, 1987; Vol. 5, Chapter 5.

11. Powell, R. G.; Weisleder, D.; Smith, C. R., Jr. J. Pharm. Sci. 1972, 61, 1227. Zhou, D. C.; Zittoun, R.; Marie, J. P. Bull. Cancer 1995, 82, 987.

12. Zhou, J. Y.; Chen, D. L.; Shen, Z. S.; Koeffler, H. P. Cancer Res. 1990, 50, 2031.

13. Bates, R. B.; Cutler, R. S.; Freeman, R. M. J. Org. Chem. 1977, 42, 4162. Hiranuma, S.; Shibata, M.; Hudlicky, T. J. Org. Chem. 1983, 48, 5321. Tse, I.; Snieckus, V. J. Chem. Soc., Chem. Commun. 1976, 505. Bryce, M. R.; Gardiner, J. M. Tetrahedron 1988, 44, 509. Fang, F. G.; Maier, M. E.; Danishefsky, S. J. J. Org. Chem. 1990, 55, 831. Sha, C. K.; Young, J. J.; Yeh, C. P.; Chang, S. C.; Wang, S. L. J. Org. Chem. 1991, 56, 2694.

14. For leading references, see: Lin, X.; Kavash, R. W.; Mariano, P. S. J. Org. Chem. 1996, 61, 7335.

15. Isono, N.; Mori, M. J. Org. Chem. 1995, 60, 115.

16. Grubbs, R. H.; Miller, S. J.; Fu, G. C. Acc. Chem. Res. 1995, 28, 446. Schuster, M.; Blechert, S. Angew. Chem., Int. Ed. Engl. 1997, 36, 2036.

17. Padwa, A.; Krumpe, K. E. Tetrahedron 1992, 48, 5385. Padwa, A.; Weingarten, M. D. Chem. Rev. 1996, 96, 223. Adams, J.; Spero, D. M. Tetrahedron 1991, 47, 1765. Doyle, M. P. Chem. Rev. 1986, 86, 919. Doyle, M. P. Comprehensive Organometallic Chemistry Il; Hegedus, L., Ed.; Pergamon Press: Oxford, 1995; Vol. 12, p 387. Taber, D. F. Comprehensive Organic Synthesis; Trost, B. M.; Fleming, I., Eds.; Pergamon Press: Oxford, 1990; Vol. 3, p 1045.

18. Zibuck, R.; Streiber, J. M. J. Org. Chem. 1989, 54, 4717.

19. For reports regarding the superiority of copper catalysts for generation of onium ylides, see: West, F. G.; Naidu, B. N.; Tester, R. W. J. Org. Chem. 1994, 59, 6892. Clark, J. S.; Krowiak, S. A.; Street, L. J. Tetrahedron Lett. 1993, 34, 4385.

20. Both compounds 24 and 25 consisted of a 1:1-mixture of diastereomers.

21. For a similar reaction in the 6,6-system, see: Zaragoza, F. Synlett 1995, 237. 